\title{
Sewage Markers as Determinants to Differentiate Origins of Emerging Organic Pollutants in an Urban Sri Lankan Water Drainage Network
}

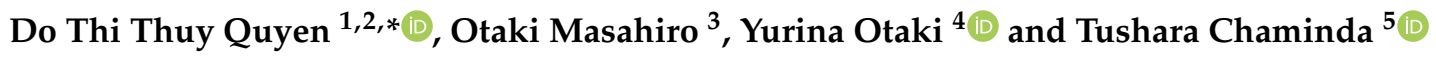 \\ 1 Department of Human Centered Engineering, Ochanomizu University, Tokyo 112-8610, Japan \\ 2 Faculty of Environment, Vietnam National University, Ho Chi Minh City-University of Science, \\ Ho Chi Minh City 700000, Vietnam \\ 3 Faculty of Core Research, Natural Science Division, Ochanomizu University, Tokyo 112-8610, Japan; \\ otaki.masahiro@ocha.ac.jp \\ 4 Graduate School of Social Sciences, Hitotsubashi University, Tokyo 186-8601, Japan; yurina.otaki@r.hit-u.ac.jp \\ 5 Faculty of Engineering, University of Ruhuna, Hapugala, Galle 8000, Sri Lanka; tusharac@cee.ruh.ac.lk \\ * Correspondence: doquyen111@gmail.com or g1970704@edu.cc.ocha.ac.jp; Tel.: +81-70-48116413
}

\section{check for}

updates

Citation: Quyen, D.T.T.; Masahiro, O.; Otaki, Y.; Chaminda, T. Sewage Markers as Determinants to Differentiate Origins of Emerging Organic Pollutants in an Urban Sri Lankan Water Drainage Network. Water 2021, 13, 2898. https:/ / doi.org/10.3390/w13202898

Academic Editors: Satoshi Takizawa, Takashi Hashimoto and Shinobu Kazama

Received: 6 August 2021

Accepted: 12 October 2021

Published: 15 October 2021

Publisher's Note: MDPI stays neutral with regard to jurisdictional claims in published maps and institutional affiliations.

Copyright: (c) 2021 by the authors. Licensee MDPI, Basel, Switzerland. This article is an open access article distributed under the terms and conditions of the Creative Commons Attribution (CC BY) license (https:// creativecommons.org/licenses/by/ $4.0 /)$.

\begin{abstract}
Urban sanitation is a major challenge during the rapid urbanization being experienced by developing countries, as a low sewerage infrastructure capacity and irregular onsite wastewater treatment raise the risk of surface water contamination. The application of specific sewage markers to characterize contaminant sources is therefore essential for managing urban sanitation issues. In this study, we investigated the concentrations of eight sewage markers (acetaminophen, caffeine, carbamazepine, cotinine, sulfamethoxazole, sulfapyridine, atenolol, and acesulfame) in various water sources within urban area of the Galle City, Sri Lanka. The total concentration of the eight markers was in the order of hospital discharge $>$ sewage treatment plant (STP) influent $>$ surface drainage system. Among the eight selected markers, acetaminophen was dominant in hospital discharge $(70.2-123.6 \mu \mathrm{g} / \mathrm{L})$ while caffeine was the largest contributor to STP influent (16.2-68.7 $\mu \mathrm{g} / \mathrm{L})$ and surface drainage $(0.95-21.73 \mu \mathrm{g} / \mathrm{L})$. We then proposed and tested a set of criteria for evaluating the applicability of markers, including removal efficiency, concentration magnitude, excretion rate, and wastewater burden. The labile markers caffeine and acetaminophen were suitable for characterizing domestic gray and black wastewater, respectively. These results imply that the city's drainage system receives both domestic graywater and human excretion, likely due to insufficient on-site sanitation systems. The conservative marker carbamazepine was useful for tracking hospital residues over long distances; these results imply that hospital wastewater treatment was not working properly, accounting for pharmaceutical residues reaching surface water via a hidden discharges connected to the drainage system.
\end{abstract}

Keywords: sewage markers; urban sanitation; surface water; caffeine; acetaminophen; carbamazepine

\section{Introduction}

According to the estimates and projections of the world urban and rural populations published by the United Nations, over half of the global population currently lives in urban areas. It is estimated that by 2050, the urban population will be 6.68 billion, compared to 3.09 billion in rural areas. The urbanization rate is two- to threefold more rapid in less developed regions than developed regions. The rate of change is projected to be fivefold in the near future [1].

In developing countries, rapid urbanization often exceeds urban infrastructure development, especially in terms of wastewater management [2]. Poor wastewater management and the outdated sanitation facilities continuously pose a potential pollution problem for the aquatic environment in the developing context [3-5]. The source of contaminants is 
difficult to identify because discharge pipes are often underground and disposed together with rainwater drainage. This raises the need for reliable markers to differentiate the pollutants' source in order to preserve healthy urban landscape and water quality and enhance environmental protection regulation.

Among the wastewater markers, the active compounds in pharmaceuticals have recently drawn attention [6]. Pharmaceuticals are ubiquitous in the aquatic environment in trace levels, and the main release pathway of pharmaceuticals into the environment is through human wastewater $[7,8]$. Ecotoxicology tests have demonstrated acute effects of high concentrations (g/L) of some compounds, such as antibiotics, diclofenac, ibuprofen, and carbamazepine, on fish, Daphnia, algae, and bacteria [7]. The potential human health hazards, however, was thought to be negligible [9-11]. Therefore, it is interesting to consider their occurrence as sewage markers due to various advantages, such as their high detection frequency, the availability of resistant markers, and especially the specificity to human fecal waste [6]. A number of application studies regarding pharmaceuticals in groundwater, surface water, and drinking water in developed countries have been well documented [7,11-13]. However, the number of studies on pharmaceuticals in the water environment and their application in wastewater tracking in developing countries is still limited [14-18].

Noting that factors such as land use, population, and sanitation types are essential to selecting appropriate markers [6], additional data on pharmaceuticals in urban sanitation in the developing context are essential. In this study, we tested a set of criteria for identifying suitable chemical markers capable of distinguishing raw human excretion, graywater, and hospital contributions to the drainage system in Galle City, the ninth-largest urban area in Sri Lanka. Almost one-fifth of the Sri Lankan population is living in urban settings. Basic sanitation access in urban Sri Lanka has grown slightly, from $85 \%$ to $88 \%$, over the period of 2000-2015 [19]. A 2016 Sri Lankan National Demographic and Health Survey reported that at that time $80 \%$ of the urban population relied on simple latrines, with only a negligible 5\% equipped with a septic tank, and it remains unknown whether Sri Lankan urban on-site sanitation meets the requirements of UN sustainable development goals [20]. The sanitation conditions here are representative of other growing urban areas in low-income countries. The study results can provide a basis for improved wastewater management in Sri Lanka and elsewhere.

\section{Materials and Methods}

\subsection{Pre-Survey}

The center of Galle City (Galle Four Gravet Divisional Secretariat) has the highest population density in the Southern Province $\left(4212\right.$ per $\left.\mathrm{km}^{2}\right)$ [20], but the city has no centralized sewage treatment plants. We initially investigated the sanitation situation here using a questionnaire survey of 31 random local households during October 2019 (Supplementary Materials) to assess how toilet/laundry/bathroom/kitchen wastewater was collected and disposed of on-site; options included septic systems, pit latrines, and direct discharge (open defecation).

\subsection{Sample Collection}

We collected water samples at sites representative of sewage treatment plant (STP) influent and effluent, hospital discharge, and surface water. Samples were collected in $50 \mathrm{~mL}$ polypropylene bottles (duplicated at each sampling site), acidified to $\mathrm{pH} 2$ using $1 \mathrm{M}$ hydrochloric acid, and kept frozen before transportation to Tokyo, Japan. Three sampling sites were considered.

The Hikkaduwa STP $\left(6^{\circ} 8^{\prime} 54.85^{\prime \prime} \mathrm{N}, 80^{\circ} 6^{\prime} 34.53^{\prime \prime} \mathrm{E}\right.$, not shown on the map) is the only municipal wastewater treatment facility in the Southern Province. This STP receives and treats domestic wastewater of Hikkaduwa town, located $20 \mathrm{~km}$ northwest from the study site. It uses 2 facultative ponds $\left(6500 \mathrm{~m}^{3}\right.$ and $\left.6300 \mathrm{~m}^{3}\right)$ and a polishing pond $\left(7000 \mathrm{~m}^{3}\right)$ to achieve a retention time of $3-4$ days before discharging treated water into a natural lake. 
Influent samples were collected after the sand-screening stage, while effluent samples were collected from the discharge mouth of the polishing pond.

Karapitiya Teaching Hospital is the largest national hospital in the Southern Sri Lanka with 600 beds. Its on-site sewage treatment facility uses an activated sludge process followed by chlorination and discharges the treated water into the municipal drainage network. Hospital-treated discharge was collected at the effluent mouth $\left(6^{\circ} 3^{\prime} 54.34^{\prime \prime} \mathrm{N}\right.$, $\left.80^{\circ} 13^{\prime} 30.06^{\prime \prime} \mathrm{E}\right)$.

The Galle municipal drainage network consists of the Moragoda, Moda, and Kepu canals, which mainly function to mitigate floods caused by excess storm water during the long rainy season from October to March. However, these canals also receive wastewater from residential areas as well as treated effluent from hospital wastewater. Grab samples were collected from the middle of these channels using a rope and a stainless-steel bucket.

\subsection{Chemicals and Standards}

The target chemical markers included the artificial sweetener acesulfame (ACS), the stimulants caffeine (CAF), the tobacco metabolite cotinine (COT), over-the-counter acetaminophen (ACT), and four prescribed pharmaceuticals (atenolol, ATE; carbamazepine, CBZ; sulfamethoxazole, SFM; and sulfapyridine, SFP). This list was selected based on three criteria: (i) detection in screening test results from the Hikkaduwa STP (Table S1), (ii) a literature review of ubiquitous chemical markers in surface water, and (iii) an adaptation of current analysis methodology. High-purity grade (>98\%) pharmaceutical standards and internal standards were purchased from Sigma-Aldrich (Darmstadt, Germany). Further details of the target compounds are provided in the SI. Stock solutions were prepared in $\mathrm{MeOH}$ and stored in a refrigerator at $-20^{\circ} \mathrm{C}$. Mobile phase solutions (LC/MS grade), water, and formic acid were obtained from Wako (Tokyo, Japan).

\subsection{LC-MS/MS Analysis}

Prior to analysis, samples were thawed and filtered by a single-use $0.2 \mu \mathrm{m}$ syringe filter with a regenerated cellulose membrane (Minisart RC 4, Sartorius ${ }^{\mathrm{TM}}$, Germany). Filtered samples were transferred into a $1.5 \mathrm{~mL}$ glass amber vial and spiked with internal standards. Samples were then ready to be injected into an LC-MS/MS. The total time from sample collection to analysis was 4 days. Instrumental analysis was carried out using a DIONEX UltiMate 3000 (Thermo Scientific, Waltham, MA, USA) coupled to a triple quadrupole mass spectrometer (MS/MS) (ABSciex 5500 QTRAP (Sciex, Concord, Ontario, Canada). Chromatographic separation was achieved on a Kinetex Biphenyl column $(2.6 \mu \mathrm{m}, 100 \AA$, LC Column $50 \mathrm{~mm} \times 2.1 \mathrm{~mm}$, Phenomenex), following a published method [21]. A 10point calibration standard curve ranging from 0.1 to $100 \mu \mathrm{g} / \mathrm{L}$ was used for all substances except carbamazepine $(0.01-10 \mu \mathrm{g} / \mathrm{L})$. A blank sample was added to the HPLC run after each 10 samples. Details of method validation are included in the SI.

\subsection{Proposed Method for Evaluating Pollutant Sources in Surface Water}

2.5.1. Removal Efficiency (RE) in the STP

Following previous research suggesting the use of the chemical marker attenuation rate during treatment in the STP to determine persistence [13-15], the removal efficiency was estimated using influent and effluent data from the Hikkaduwa STP:

$$
R E(\%)=\frac{C_{i n f}-C_{e f f}}{C_{i n f}} \times 100
$$

where $C_{\text {inf }}$ and $C_{\text {eff }}$ are the concentrations of specific compounds in the raw and treated wastewater, respectively. Compounds with $R E>90 \%$ were determined to be labile markers, while conservative markers were defined as compounds with $R E<25 \%$. 


\subsubsection{Concentration Magnitude (CM) of Target Compounds in Raw Wastewater}

As a reliable wastewater chemical indicator should be significantly higher than the analytical sensitivity $[15,16]$, we defined concentrations 50 times higher than the instrument quantification limit (IQL) in raw wastewater as one screening criterion:

$$
C M_{w w}=\frac{C_{w w}}{I Q L}
$$

where $C M_{w w}$ is the magnitude of the concentration of a specific compound and $C_{w w}$ is the average concentration in the raw wastewater source (either STP or hospital discharge). Details of IQL determination are given in the SI.

\subsubsection{Excretion Rate}

The target compounds represent either daily consumption (acesulfame, caffeine, and cotinine) or oral medication (acetaminophen, atenolol, carbamazepine, sulfamethoxazole, and sulfapyridine). Once consumed, some compounds are transformed during metabolism while others remain unchanged, before all are excreted along with urine and feces. As it is essential to consider this factor as input information when considering the origin of human wastewater, we collected excretion rates from previous studies and summarized these in the Results and Discussion section.

\subsubsection{Wastewater Burden (WB) in Surface Water}

The term $W B$ was adapted from a previous study [15] to estimate the wastewater load to surface water using a conservative indicator:

$$
W B=\frac{C_{\text {sur }}}{C_{w w}} \times 100(\%)
$$

where $C_{\text {sur }}$ is the concentration of a conservative indicator in the surface water at each sampling site and $C_{w w}$ is the average concentration of a conservative indicator in the effluent wastewater.

\section{Results and Discussion}

\subsection{Study Area Sanitation}

Our survey data showed that pits are dominantly used for on-site sanitation in Galle City $(\sim 80 \%$, Table 1$)$, consistent with national data from the 2016 Demographic Health Survey [20]. However, the total lack of sewerage in Galle City is well behind the national rate of $12.3 \%$. This gap is compensated for by a higher percentage of septic tank use (19.2\%). Smaller living spaces in urban areas mean less space to cover and safely abandon full latrines and construct new ones or to replace these with more advanced sanitation facilities [5].

Table 1. Distribution of sanitation infrastructure nationally [20] and in Galle City (this study).

\begin{tabular}{cccc}
\hline \multirow{2}{*}{ Wastewater } & Facility Type & $\begin{array}{c}\text { National } \\
\mathbf{( \% )}\end{array}$ & $\begin{array}{c}\text { Galle City } \\
\mathbf{( \% )}\end{array}$ \\
\hline \multirow{2}{*}{ Blackwater } & Improved sewerage & 12.3 & 0 \\
\cline { 2 - 4 } & Improved septic & 5.1 & 19.2 \\
\cline { 2 - 4 } & Improved pit latrine & 80.3 & 80.8 \\
\cline { 2 - 4 } & Open defecation & 0.4 & 0 \\
\hline \multirow{2}{*}{$\begin{array}{c}\text { Graywater } \\
\text { (laundry, kitchen, bathroom) }\end{array}$} & Direct discharge & n.a. & 61.3 \\
\cline { 2 - 4 } & Septic/pit & n.a. & 38.7 \\
\hline n.a.: not available. & & &
\end{tabular}


Wastewater from kitchens, bathrooms, and laundry areas (i.e., graywater) has traditionally been given lower priority than excretory effluent in sanitation management [21] In rural areas, each house has a dedicated space where discharged graywater can infiltrate into the soil. In contrast, urban graywater is often discharged into drainage networks; for example, two-thirds of the households surveyed reported that their graywater is directly discharged into the city's canals (Supplementary Materials). To distinguish the potential pharmaceutical pathways in black water and graywater, questions about disposal practices were included in the survey, with a majority of respondents selecting "disposed with solid waste" or "burned with solid waste." In general, domestic graywater is unlikely to include pharmaceuticals.

\subsection{Occurrence and Removal Efficiency of Targeted Compounds in Raw Wastewater}

The concentrations of target compounds in raw wastewater from the Hikkaduwa STP and Karapitiya Hospital were comparable with those frequently detected in previous studies in developed countries, confirming the appropriateness of the selected list (Table 2).

Table 2. Concentration ranges and means $(\mu \mathrm{g} / \mathrm{L})$ for wastewater compounds in urban STP influent and hospital effluent from this study $(n=3)$ and three previous studies.

\begin{tabular}{|c|c|c|c|c|c|c|c|c|c|c|}
\hline \multirow[t]{4}{*}{$\begin{array}{c}\text { Target } \\
\text { Compounds }\end{array}$} & \multirow[t]{4}{*}{$\begin{array}{c}\mathrm{IQL}^{\mathrm{a}} \\
\mu \mathrm{g} / \mathrm{L}\end{array}$} & \multicolumn{4}{|c|}{ STP Influent } & \multicolumn{5}{|c|}{ Hospital Wastewater } \\
\hline & & \multicolumn{3}{|c|}{ This Study } & \multirow{3}{*}{$\begin{array}{l}\text { Previous } \\
\text { Studies } \\
\text { Influent }\end{array}$} & \multirow{2}{*}{\multicolumn{3}{|c|}{$\begin{array}{c}\text { This Study } \\
\text { Effluent }\end{array}$}} & \multicolumn{2}{|c|}{ Previous Studies } \\
\hline & & \multirow[b]{2}{*}{ Range } & \multirow[b]{2}{*}{ Mean } & \multirow[b]{2}{*}{$\mathbf{C M}$} & & & & & Influent & Effluent \\
\hline & & & & & & Range & Mean & $\mathrm{CM}^{*}$ & Mean/M & ian Value \\
\hline $\mathrm{ACT}$ & 0.15 & $29.7-44.3$ & 39.0 & 260 & $\begin{array}{l}116.0^{\mathrm{a}} \\
77.7^{\mathrm{b}}\end{array}$ & $70.2-123.6$ & 92.8 & 625 & $813.5^{\mathrm{a}}$ & $0.04^{\mathrm{a}}$ \\
\hline CAF & 0.15 & $16.2-68.7$ & 49.1 & 327 & $35.2^{b}$ & $12.5-23.7$ & 16.6 & 110 & $28.2^{c}$ & $0.35^{c}$ \\
\hline CBZ & 0.003 & $0.07-0.24$ & 0.13 & 43 & $\begin{array}{l}0.53^{\mathrm{a}} \\
0.37^{\mathrm{b}}\end{array}$ & $0.44-0.60$ & 0.50 & 167 & $\begin{array}{c}0.3^{\mathrm{a}} \\
0.08^{\mathrm{c}}\end{array}$ & $\begin{array}{c}0.63^{\mathrm{a}} \\
0.015^{\mathrm{c}}\end{array}$ \\
\hline COT & 0.1 & $1.9-2.2$ & 1.9 & 21 & n.a. & $1.36-2.35$ & 1.86 & 21 & n.a. & n.a. \\
\hline SFM & 0.1 & $0.1-0.2$ & 0.17 & 2 & $\begin{array}{c}0.5^{\mathrm{a}} \\
0.01-0.1 \\
\mathrm{~d}\end{array}$ & $2.20-2.96$ & 2.58 & 29 & $\begin{array}{c}3.9^{\mathrm{a}} \\
1.4^{\mathrm{c}} \\
0.1-1^{\mathrm{d}}\end{array}$ & $\begin{array}{c}0.81^{\mathrm{a}} \\
0.21^{\mathrm{c}} \\
0.001-0.01 \\
\mathrm{~d}^{\mathrm{m}}\end{array}$ \\
\hline SFP & 0.1 & $0.38-0.47$ & 0.44 & 5 & $0.072-1^{d}$ & $2.05-2.32$ & 2.18 & 24 & $0.01-0.1^{d}$ & $b q l^{d}$ \\
\hline ATE & 0.15 & $0.19-0.48$ & 0.30 & 2 & $2.4^{\mathrm{a}}$ & $0.54-1.11$ & 0.79 & 4 & $3.2^{\mathrm{a}}$ & $0.019^{a}$ \\
\hline ACS & 0.15 & $8.2-10.6$ & 9.0 & 60 & $11.5^{b}$ & $0.98-2.0$ & 1.43 & 9 & n.a. & n.a. \\
\hline
\end{tabular}

a Urban WWTP in France with a flow rate of $5355 \mathrm{~m}^{3}$ day ${ }^{-1}$; hospital with 450 beds, $n=27$ [22]; b WWTP in Singapore, $n=16$ [23]; ${ }^{\mathrm{c}}$ Ioannina Hospital in Greece, 800 beds, flow rate $550 \mathrm{~m}^{3}$ day $^{-1}, n=32$ [24]; ${ }^{\mathrm{d}} 24 \mathrm{~h}$ composite sample of two urban WWTPs in Netherland; hospital with an on-site pharmafilter process including a membrane bioreactor, ozonation, granulated activated carbon, and UV treatment [25]. n.a.: not available; bql: below quantification limit; * CM: concentration magnitude; ACT: acetaminophen; CAF: caffeine; CBZ: carbamazepine; COT: cotinine; SFM: sulfamethoxazole; SFP: sulfapyridine; ATE: atenolol; ACS: acesulfame.

ACT and CAF accounted for the vast majority of the total concentrations in both STP influent and hospital discharge. In the former, the contribution of CAF and ACT equally made up $45 \%$ of the total concentration, while ACT accounted for more than $80 \%$ of the latter. The proportion of ACS, though a negligible $1 \%$ in hospital discharge, made up nearly a tenth of that in urban raw wastewater (Figure 1). 
(a) STP influent

$\sum 8$ OWCs $=0.57 \mu \mathrm{mol} / \mathrm{L}$

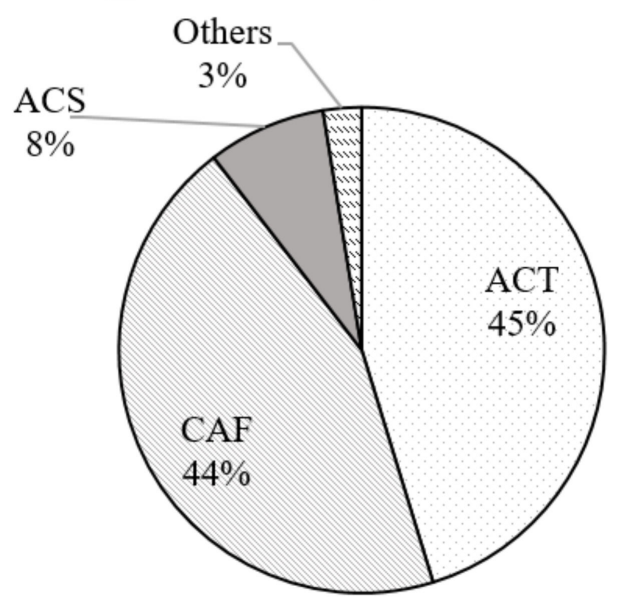

(b) Hospital discharge $\sum 8$ OWCs $=0.75 \mu \mathrm{mol} / \mathrm{L}$

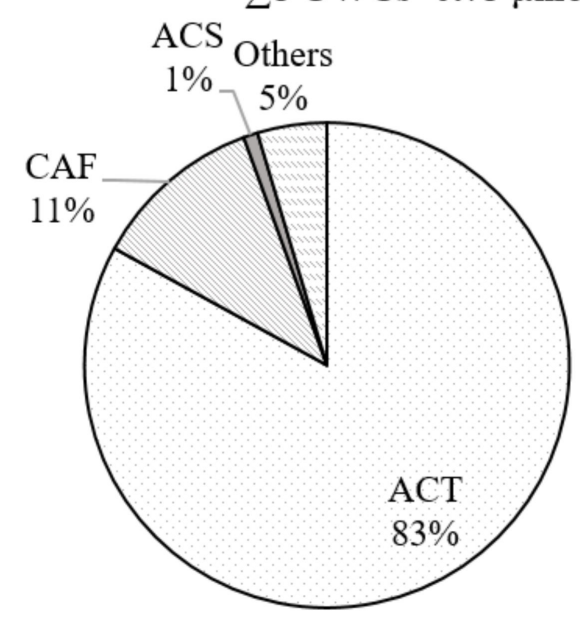

Figure 1. Relative contributions of targeted compounds in (a) raw sewage (STP influent) and (b) hospital discharge.

Despite their high concentrations in raw wastewater, up to $99 \%$ of CAF and ACT was removed by the STP (Figure 2), indicating their labile characteristic; this was consistent with other studies where CAF and ACT were present in only minute or undetected concentrations in effluent $[26,27]$. The other compounds were all categorized as conservative according to their RE values. There was no significant difference between the concentrations of ACS, ATE, COT, and SFP in the STP influent and effluent, contradicting a previous report in which the REs of ACS, ATE, and COT varied from $50 \%$ to $80 \%$. CBZ is known for its high recalcitrance to biological oxidation, as shown by its negative RE in many studies on pharmaceutical removal in STPs [28-31]. In our study, the mean concentration of CBZ in the effluent was double that in the influent, reflecting its conservative characteristic. Our SFM also had a negative RE, other than one instance where the influent was higher than the effluent $(0.1 \mu \mathrm{g} / \mathrm{L}$ and $0.4 \mu \mathrm{g} / \mathrm{L})$. Other study has reported moderate to high REs for SFM in STPs [24]. Negative REs can be explained by multiple factors, such as the conversion from conjugated metabolite parent compounds during the WWTP process or the retardation of persistent compounds onto sludge, which is released later in the effluent [27]. This could also be explained by the fact that we did not take hydraulic retention time into consideration (i.e., STP influent and effluent samples were collected on the same day) [24].

The hospital discharge samples showed that the labile compounds ACT and CAF still occurred in elevated concentrations in hospital wastewater (Table 3), although the two compounds were categorized as labile. Wiest et al. [22] documented the ready elimination of ACT in hospital wastewater; although influent ACT levels were 10 times higher than in this study $(813.5 \mu \mathrm{g} / \mathrm{L})$, it was reduced to a minute concentration $(0.04 \mu \mathrm{g} / \mathrm{L}$ in the discharge). This indicates that the current treatment process used by the Karapitiya Hospital was not sufficient to remove pharmaceutical compounds. The complicated composition of hospital discharge suggests the need for longer-term monitoring study.

\subsection{Selecting Wastewater Indicators to Differentiate Pollutant Sources}

The concentrations of ACT, CAF, and ACS in urban sewage were significantly higher than those in IQL ( $>50$ times), while ACT, CAF, and CBZ exceeded the criteria for hospital wastewater. Hence, these four were selected as wastewater indicators. The stimulant $\mathrm{CAF}$ and the artificial sweetener ACS are included in everyday beverages, such as tea, coffee, and soft drinks, so both black water and graywater may contain these compounds. However, the fact that CAF is readily degradable and entirely metabolized in the human body suggests that black water is not a major source and that it is more likely to be a graywater indicator. ACS, however, is not metabolized and is excreted unchanged 
through the kidneys. The fact that ACS can be in both graywater and human excretion makes it impossible to differentiate black water sources in surface water. However, due to the persistence of ACS during wastewater treatment, it can be used to generalize the impacts of domestic wastewater on surface water. ACT and CBZ are active pharmaceutical ingredients. The over-the-counter mild pain reliever ACT was marked as labile due to its efficient elimination in STPs (>99\%), while the prescribed CBZ is known for its great attenuation. As expected, the CBZ level was significantly lower than that of ACT in urban wastewater owing to its limited use. In terms of the excretion rate, both compounds are extensively transformed during metabolism. Our findings therefore suggest the following applications of these compounds for identifying pollutant sources in Galle City.

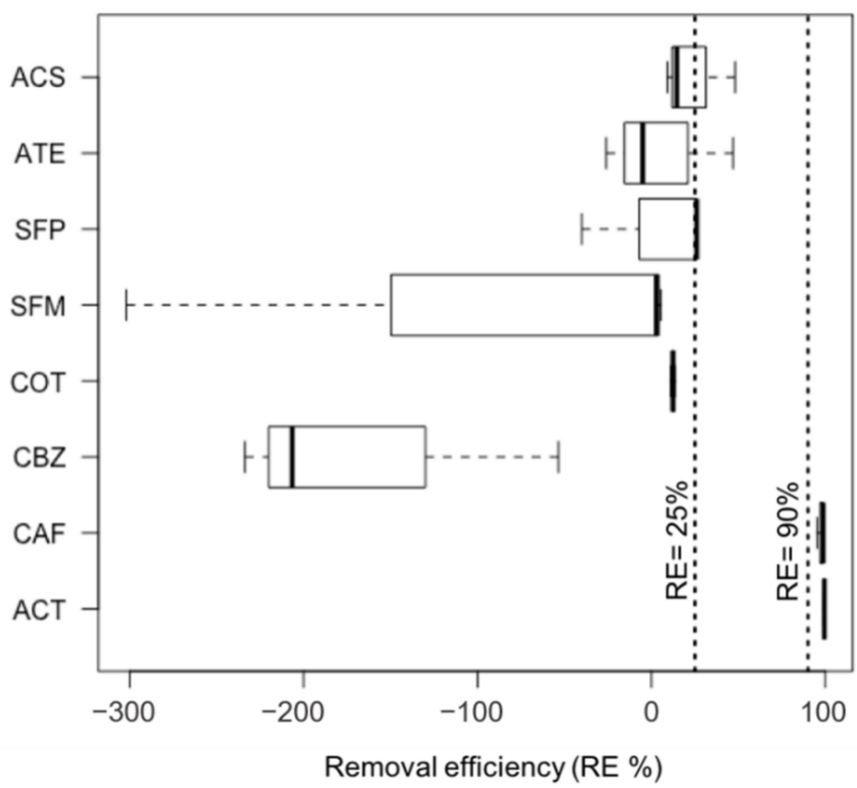

Figure 2. Removal efficiency of the eight target OWCs in the Hikkaduwa STP.

- $\quad$ CAF indicates the magnitude of graywater loading at each sampling site.

- $\quad$ ACT indicates the impact of untreated human excretion over short distances.

- ACS indicates the general impact of domestic wastewater (both black and gray) on surface water.

- CBZ indicates the presence of hospital residues over long distances.

Table 3. Indicator criteria. Note: persistency (Y: RE > 90\%; N: RE < 25\%); potential pathway (B: black water, G: graywater).

\begin{tabular}{|c|c|c|c|c|c|c|c|}
\hline Marker & Category & Persistency & $\begin{array}{l}\text { Excretion } \\
\text { Rate (\%) }\end{array}$ & $\begin{array}{l}\text { Potential } \\
\text { Pathway }\end{array}$ & $\begin{array}{c}\text { Hospital } \\
\text { Discharge } C M\end{array}$ & $\begin{array}{c}\text { Urban } \\
\text { Sewage CM }\end{array}$ & $\begin{array}{c}\text { Hospital/Urban } \\
\text { Ratio }\end{array}$ \\
\hline ACS & $\begin{array}{c}\text { Artificial } \\
\text { sweetener }\end{array}$ & $\mathrm{Y}$ & $>99$ [32] & $\mathrm{B}, \mathrm{G}$ & $<10$ & 60 & 0.2 \\
\hline $\mathrm{ACT}$ & Antipyretic & $\mathrm{N}$ & $<5$ [33] & B & 625 & 260 & 2.4 \\
\hline ATE & Beta-blocker & $\mathrm{Y}$ & $50[34]$ & B & $<10$ & $<10$ & 2.6 \\
\hline CAF & Stimulant & $\mathrm{N}$ & $<5$ [35] & G & 111 & 327 & 0.3 \\
\hline CBZ & $\begin{array}{c}\text { Neuroactive } \\
\text { drugs }\end{array}$ & Y & $<1[36]$ & B & 167 & 43 & 3.9 \\
\hline COT & $\begin{array}{l}\text { Tobacco } \\
\text { metabolite }\end{array}$ & Y & $13 *[37]$ & B & 21 & 21 & 1.0 \\
\hline SFM & Antibiotic & Y & $<20[38]$ & B & 29 & $<10$ & 15.5 \\
\hline SFP & Antibiotic & Y & $<2$ [39] & B & 24 & $<10$ & 5.0 \\
\hline
\end{tabular}

${ }^{*}$ Calculated for consumed nicotine. ${ }^{* *}$ Concentration magnitude. 


\subsection{Implications for Pollutants in Galle City Canal Drainage}

Figure 3 presents the total concentration of each marker by sampling site. Notably, elevated CAF concentrations were detected in the middle of the Moda canal (MODA3) and Moragoda canal (MOR3 and MOR4), which can be explained by the higher-density housing in those areas. In addition, the dilution effect of seawater might have lowered the graywater flow in estuary sampling locations. However, two sampling sites in the Kepu canal had equally high total concentrations.

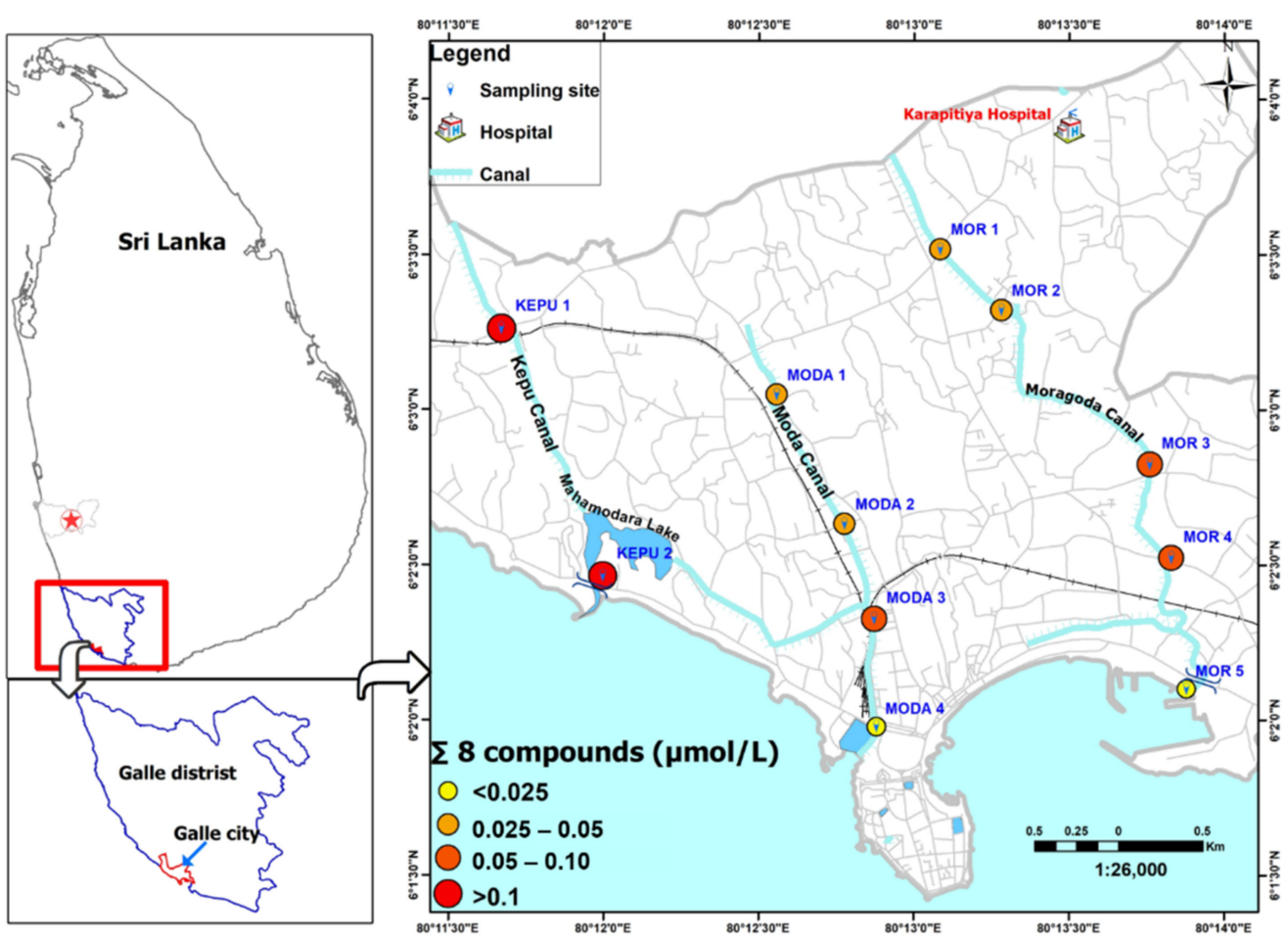

Figure 3. Total concentrations of eight sewage markers at sampling sites in Galle City, Sri Lanka. Sampling sites were numbered from upstream to downstream, starting at number 1.

$\mathrm{ACT}$ and CAF were used to evaluate the impact of urban wastewater as both are ubiquitous in the drainage system within a comparable range (ACT $0.57-4.70 \mu \mathrm{g} / \mathrm{L}$ and CAF 0.95-21.73 $\mu \mathrm{g} / \mathrm{L}$ ) (Figure 4a). CAF (representing graywater discharge) was dominant at all sampling points except for MOR5. Based on end-use data [40] and the graywater direct discharge rate of $80 \%$ obtained in this study, we estimated that $\sim 700 \mathrm{~m}^{3}$ of untreated graywater is disposed of daily into the city's drainage system. We therefore predicted that graywater from domestic discharge is dominant in the drainage system, as demonstrated by the high CAF concentrations. In contrast, the lower ACT levels represent the impact of human excretion on the drainage system, where the most relevant source of black water is likely the insufficient RE of current on-site sanitation methods. This was supported by the trace occurrence of other pharmaceutical compounds. Another possibility is the misconnection of toilet wastewater to the drainage system.

The WB criteria was applied for the two conservative compounds (ACS and CBZ) to evaluate the impact of hospital wastewater (Figure 4b). Assuming that the urban raw sewage in the Hikkaduwa STP represents the combined sewage discharge to surface water, we used the ratio of ACS concentration at each sampling site to the average concentration of Hikkaduwa STP effluent (ACS/effluent) to normalize the WB from urban sewage to the drainage system. As CBZ also occurred significantly in the hospital wastewater, we used the ratio of $\mathrm{CBZ}$ concentration in each sample to the mean CBZ concentration of hospital discharge (CBZ/hospital) to evaluate the potential WB burden at a single site. The WB factor was in the same range in the Kepu and Moda canals, indicating similar levels for 
both markers. Their trend was similar to that of ACT (Figure 4a), supporting the hypothesis that ACT, ACS, and CBZ were derived from black water of the same origin. However, ACS and CBZ were remarkably elevated at sampling sites MOR3 and MOR4 in the Moragoda canal, where the CBZ burden was approximately four times higher than that of ACS at that site. It is therefore likely that other sources, rather than black water, discharge into the Moragoda canal between sites MOR2 and MOR3. The foremost cause of this discrepancy is thought to be hospital discharge with a high concentration of CBZ. The hospital nearest to the elevated sites is the Karapitiya Hospital, where discharge was collected as a reference for hospital wastewater. The distance from this hospital and MOR3 is $<2 \mathrm{~km}$, as measured on Google Maps. Since CBZ has been recognized for its preservation, it is highly possible that CBZ from the hospital is transported to the mainstream via small tributaries of the drainage system. In fact, one study conducted in South Africa detected CBZ as far as 6-8 km downstream of discharge from a centralized STP [16]. Further data collection is required to determine exactly how seasonal variation affects the flow and concentration in the drainage system.
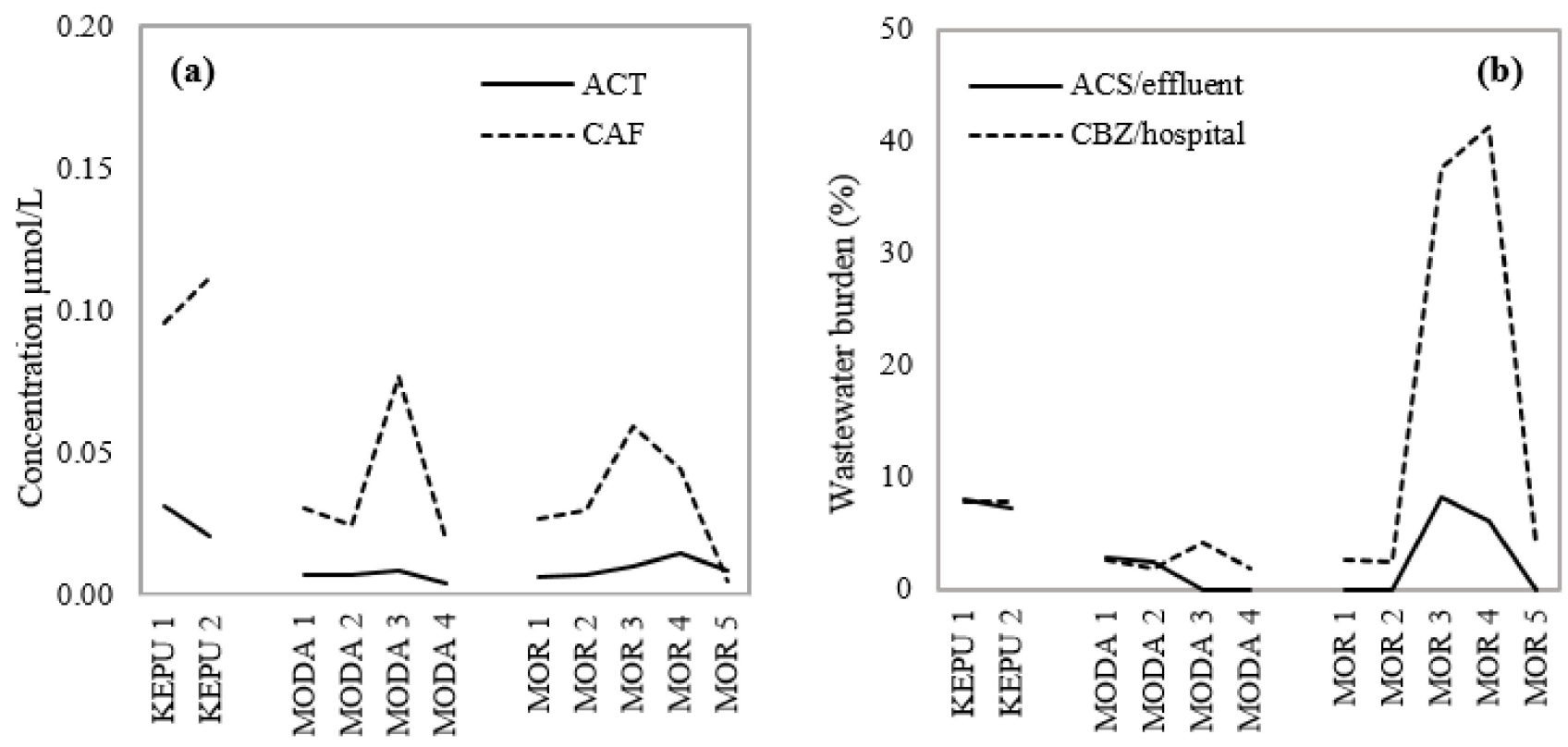

Figure 4. (a) Concentrations of labile compounds ACT and CAF in drainage samples and (b) wastewater burden (WB) factor of conservative compounds ACS and CBZ in drainage samples.

\section{Conclusions}

Our results highlight existing issues in urban sanitation in Galle City, Sri Lanka, where graywater is discharged untreated and black water is discharged after simple treatment, while proposing and testing a process for identifying wastewater sources. Consideration of the magnitude, persistency, and metabolism rates of eight target sewage makeres in urban wastewater (including black water, graywater, and hospital wastewater) suggests that CAF is useful for understanding the magnitude of graywater discharge and the presence of labile ACT is evidence of the mixing of raw black water in surface water. We recommend the widespread installation of well-functioning septic treatment systems that can manage both black water and graywater. Treated hospital wastewater included trace amounts of active pharmaceutical ingredients that could contribute to surface water pollutants. The use of persistent indicators, such as CBZ, to identify hospital wastewater discharges into the drainage network proved useful. Although the number of target compounds in this study was small, these were clearly identified in local sewerage and are among the most ubiquitous compounds in human wastewater. 
Supplementary Materials: The following are available online at https:/ / www.mdpi.com/article / 10.3390/w13202898/s1: Table S1: Screening test result of Hikkaduwa wastewater, Table S2: Physicochemical properties of 8 targeted analytes, Table S3: MS setting, Table S4: Laboratory report, pre-survey questionnaire.

Author Contributions: D.T.T.Q. was responsible for methodology, validation, investigation, formal analysis, data curation, and writing of the original draft; O.M. was responsible for supervision, project administration, and funding acquisition; Y.O. was responsible for supervision, survey design, and project administration; and T.C. was responsible for conceptualization and resources. All authors have read and agreed to the published version of the manuscript.

Funding: This research was funded by the Japan Society for the Promotion of Science, Grants-in-Aid for Scientific Research JP20H04391.

Data Availability Statement: Not applicable.

Acknowledgments: We would like to thank O.L.L. Lekamge (Ruhuna University) for the contribution to the field sampling and pre-surveying.

Conflicts of Interest: The authors declare no conflict of interest. The funders had no role in the design of the study; in the collection, analyses, or interpretation of data; in the writing of the manuscript; or in the decision to publish the results.

\section{References}

1. United Nation, Department of Economic and Social Affairs, Population Division. World Urbanization Prospects; The 2018 Revision (ST/ESA/SER.A/420); United Nations: New York, NY, USA, 2019; p. 9.

2. WHO; UNICEF. Progress on Drinking Water, Sanitation and Hygiene: 2017 Update and SDG Baseline; WHO: Geneva, Switzerland, 2017; p. 66.

3. Wicken, J.; Tep, M.; Seth, K.; Etherington, A. Water, Sanitation and Hygiene (WASH) Situation and Issues for Urban Poor People and Vulnerable Groups, Cambodia; WaterAid Cambodia: Phnom Penh, Cambodia, 2015; p. 101.

4. Freeman, M.C.; Garn, J.V.; Sclar, G.D.; Boisson, S.; Medlicott, K.; Alexander, K.T.; Penakalapati, G.; Anderson, D.; Mahtani, A.G.; Grimes, J.; et al. The impact of sanitation on infectious disease and nutritional status: A systematic review and meta-analysis. Int. J. Hyg. Environ. Health 2017, 220, 928-949. [CrossRef] [PubMed]

5. Hawkins, P.; Blackett, I.; Heymans, C. Poor-Inclusive Urban Sanitation: An Overview; World Bank, Water and Sanitation Program (WSP); World Bank: Washington, DC, USA, 2013.

6. Lim, F.Y.; Ong, S.L.; Hu, J. Recent Advances in the Use of Chemical Markers for Tracing Wastewater Contamination in Aquatic Environment: A Review. Water 2017, 9, 143. [CrossRef]

7. Kümmerer, K. The presence of pharmaceuticals in the environment due to human use-Present knowledge and future challenges. J. Environ. Manag. 2009, 90, 2354-2366. [CrossRef] [PubMed]

8. Boxall, A.B.; Rudd, M.; Brooks, B.; Caldwell, D.J.; Choi, K.; Hickmann, S.; Innes, E.; Ostapyk, K.; Staveley, J.P.; Verslycke, T.; et al. Pharmaceuticals and Personal Care Products in the Environment: What Are the Big Questions? Environ. Health Perspect. 2012, 120, 1221-1229. [CrossRef]

9. Simazaki, D.; Kubota, R.; Suzuki, T.; Akiba, M.; Nishimura, T.; Kunikane, S. Occurrence of selected pharmaceuticals at drinking water purification plants in Japan and implications for human health. Water Res. 2015, 76, 187-200. [CrossRef]

10. Schwab, B.W.; Hayes, E.P.; Fiori, J.M.; Mastrocco, F.J.; Roden, N.M.; Cragin, D.; Meyerhoff, R.D.; D’ Aco, V.J.; Anderson, P.D. Human pharmaceuticals in US surface waters: A human health risk assessment. Regul. Toxicol. Pharmacol. 2005, 42, 296-312. [CrossRef]

11. Gaffney, V.D.J.; Almeida, C.M.; Rodrigues, A.; Ferreira, E.; Benoliel, M.J.; Cardoso, V.V. Occurrence of pharmaceuticals in a water supply system and related human health risk assessment. Water Res. 2015, 72, 199-208. [CrossRef]

12. Tran, N.H.; Reinhard, M.; Gin, K.Y.-H. Occurrence and fate of emerging contaminants in municipal wastewater treatment plants from different geographical regions-a review. Water Res. 2018, 133, 182-207. [CrossRef]

13. Gaston, L.; Lapworth, D.J.; Stuart, M.; Arnscheidt, J. Prioritization Approaches for Substances of Emerging Concern in Groundwater: A Critical Review. Environ. Sci. Technol. 2019, 53, 6107-6122. [CrossRef]

14. Kumar, M.; Ram, B.; Honda, R.; Poopipattana, C.; Canh, V.D.; Chaminda, T.; Furumai, H. Concurrence of antibiotic resistant bacteria (ARB), viruses, pharmaceuticals and personal care products (PPCPs) in ambient waters of Guwahati, India: Urban vulnerability and resilience perspective. Sci. Total. Environ. 2019, 693, 133640. [CrossRef]

15. Yang, Y.-Y.; Zhao, J.-L.; Liu, Y.-S.; Liu, W.-R.; Zhang, Q.-Q.; Yao, L.; Hu, L.-X.; Zhang, J.-N.; Jiang, Y.-X.; Ying, G.-G. Pharmaceuticals and personal care products (PPCPs) and artificial sweeteners (ASs) in surface and ground waters and their application as indication of wastewater contamination. Sci. Total. Environ. 2018, 616-617, 816-823. [CrossRef]

16. Vumazonke, S.; Khamanga, S.M.; Ngqwala, N. Detection of Pharmaceutical Residues in Surface Waters of the Eastern Cape Province. Int. J. Environ. Res. Public Health 2020, 17, 4067. [CrossRef] [PubMed] 
17. Do, T.T.Q.; Otaki, M.; Otaki, Y.; Chaminda, T.; Wijesinghe, I.S. Pharmaceutical contaminants in shallow groundwater and their implication to poor sanitation facilities in low-income countries. Environ. Toxicol. Chem. 2021, 1-9.

18. Valdez-Carrillo, M.; Abrell, L.; Ramírez-Hernández, J.; Reyes-López, J.A.; Carreón-Diazconti, C. Pharmaceuticals as emerging contaminants in the aquatic environment of Latin America: A review. Environ. Sci. Pollut. Res. 2020, 27, 44863-44891. [CrossRef]

19. ADB/JICA/World Bank. Toward Sustainable Water and Sanitation Services in Sri Lanka: Beyond Sustainable Development Goals to Supporting the National Economic Vision; World Bank Publications: Washington, DC, USA, 2016; p. 13.

20. Sri Lanka Department of Census and Statistics, Ministry of National Policies and Economic Affairs. Sri Lanka Demographic and Health Survey 2016; S\&S Printers: Colombo, Sri Lanka, 2017.

21. Morel, A.; Diener, S. Greywater Management in Low and Middle-Income Countries, Review of Different Treatment Systems for Households or Neighbourhoods; Swiss Federal Institute of Aquatic Science and Technology (Eawag): Dubendorf, Switzerland, 2006.

22. Wiest, L.; Chonova, T.; Bergé, A.; Baudot, R.; Bessueille-Barbier, F.; Ayouni-Derouiche, L.; Vulliet, E. Two-year survey of specific hospital wastewater treatment and its impact on pharmaceutical discharges. Environ. Sci. Pollut. Res. 2017, 25, 9207-9218. [CrossRef] [PubMed]

23. Tran, N.H.; Reinhard, M.; Khan, E.; Chen, H.; Nguyen, V.T.; Li, Y.; Goh, S.G.; Nguyen, Q.; Saeidi, N.; Gin, K.Y.-H. Emerging contaminants in wastewater, stormwater runoff, and surface water: Application as chemical markers for diffuse sources. Sci. Total. Environ. 2019, 676, 252-267. [CrossRef] [PubMed]

24. Kosma, C.I.; Lambropoulou, D.A.; Albanis, T.A. Investigation of PPCPs in wastewater treatment plants in Greece: Occurrence, removal and environmental risk assessment. Sci. Total Environ. 2014, 466-467, 421-438. [CrossRef]

25. Paulus, G.K.; Hornstra, L.M.; Alygizakis, N.; Slobodnik, J.; Thomaidis, N.; Medema, G. The impact of on-site hospital wastewater treatment on the downstream communal wastewater system in terms of antibiotics and antibiotic resistance genes. Int. J. Hyg. Environ. Health 2019, 222, 635-644. [CrossRef] [PubMed]

26. Nguyen, H.T.; Thai, P.K.; Kaserzon, S.L.; O’Brien, J.W.; Eaglesham, G.; Mueller, J.F. Assessment of drugs and personal care products biomarkers in the influent and effluent of two wastewater treatment plants in Ho Chi Minh City, Vietnam. Sci. Total Environ. 2018, 631-632, 469-475. [CrossRef]

27. Palli, L.; Spina, F.; Varese, G.C.; Vincenzi, M.; Aragno, M.; Arcangeli, G.; Mucci, N.; Santianni, D.; Caffaz, S.; Gori, R. Occurrence of selected pharmaceuticals in wastewater treatment plants of Tuscany: An effect-based approach to evaluate the potential environmental impact. Int. J. Hyg. Environ. Health 2019, 222, 717-725. [CrossRef]

28. O’Brien, J.W.; Banks, A.P.W.; Novic, A.J.; Mueller, J.F.; Jiang, G.; Ort, C.; Eaglesham, G.; Yuan, Z.; Thai, P.K. Impact of in-Sewer Degradation of Pharmaceutical and Personal Care Products (PPCPs) Population Markers on a Population Model. Environ. Sci. Technol. 2017, 51, 3816-3823. [CrossRef]

29. Nakada, N.; Tanishima, T.; Shinohara, H.; Kiri, K.; Takada, H. Pharmaceutical chemicals and endocrine disrupters in municipal wastewater in Tokyo and their removal during activated sludge treatment. Water Res. 2006, 40, 3297-3303. [CrossRef]

30. Tran, N.H.; Hoang, L.; Nghiem, L.; Nguyen, N.M.H.; Ngo, H.H.; Guo, W.; Trinh, Q.T.; Mai, N.H.; Chen, H.; Nguyen, D.D.; et al. Occurrence and risk assessment of multiple classes of antibiotics in urban canals and lakes in Hanoi, Vietnam. Sci. Total. Environ. 2019, 692, 157-174. [CrossRef]

31. Oppenheimer, J.; Eaton, A.; Badruzzaman, M.; Haghani, A.W.; Jacangelo, J.G. Occurrence and suitability of sucralose as an indicator compound of wastewater loading to surface waters in urbanized regions. Water Res. 2011, 45, 4019-4027. [CrossRef]

32. Magnuson, B.A.; Carakostas, M.C.; Moore, N.H.; Poulos, S.; Renwick, A.G. Biological fate of low-calorie sweeteners. Nutr. Rev. 2016, 74, 670-689. [CrossRef]

33. Cummings, A.J.; King, M.L.; Martin, B.K. A kinetic study of drug elimination: The excretion of paracetamol and its metabolites in manmetabolites in man. Br. J. Pharmacol. Chemother. 1967, 29, 150-157. [CrossRef]

34. Kirch, W.; Görg, K.G. Clinical pharmacokinetics of atenolol-A review. Eur. J. Drug Metab. Pharmacokinet. 1982, 7, 81-91. [CrossRef]

35. Magkos, F.; Kavouras, S.A. Caffeine use in sports, pharmacokinetics in man, and cellular mechanisms of action. Crit. Rev. Food Sci. Nutr. 2005, 45, 535-562. [CrossRef] [PubMed]

36. Richter, W.J.; Kriemler, P.; Faigle, J.W. Newer Aspects of the Biotransformation of Carbamazepine: Structural Characterization of Highly Polar Metabolites; Springer: Boston, MA, USA, 1978; pp. 1-14. [CrossRef]

37. Heinrich-Ramm, R.; Wegner, R.; Garde, A.H.; Baur, X. Cotinine excretion (tobacco smoke biomarker) of smokers and non-smokers: Comparison of GC/MS and RIA results. Int. J. Hyg. Environ. Health 2002, 205, 493-499. [CrossRef] [PubMed]

38. Vree, T.B.; van der Ven, A.J.A.M.; Koopmans, P.P.; Va Kolmer, E.W.J.; Van Wissen, C.P.W.G.M. Pharmacokinetics of Sulfamethoxazole with its Hydroxy Metabolites and N4-Acetyl-, N1-Glucuronide Conjugates in Healthy Human Volunteers. Clin. Drug Investig. 1995, 9, 43-53. [CrossRef]

39. Schröder, H.; Campbell, D.E.S. Absorption, metabolism, and excretion of salicylazosulfapyridine in man. Clin. Pharmacol. Ther. 1972, 13, 539-551. [CrossRef] [PubMed]

40. Takagi, K.; Otaki, M.; Otaki, Y.; Chaminda, T. Availability and public acceptability of residential rainwater use in Sri Lanka. J. Clean. Prod. 2019, 234, 467-476. [CrossRef] 